\title{
Article
}

\section{Fast UHPLC-MS/MS for the Simultaneous Determination of Azithromycin, Erythromycin, Fluoxetine and Sotalol in Surface Water Samples}

\author{
Mira Azzi ${ }^{1,2}$, Sylvain Ravier ${ }^{1}$, Assem Elkak ${ }^{2}$, Bruno Coulomb ${ }^{1}\left(\mathbb{D}\right.$ and Jean-Luc Boudenne ${ }^{1, *} \mathbb{C}$ \\ 1 Department of Chemistry, Aix Marseille University, CNRS, LCE UMR 7376, 13331 Marseille, France; \\ mira.azzi@hotmail.com (M.A.); sylvain.ravier@univ-amu.fr (S.R.); bruno.coulomb@univ-amu.fr (B.C.) \\ 2 Laboratoire de Valorisation des Ressources Naturelles et Produits de Santé (LVRNPS), Faculty of Pharmacy, \\ Rafic Hariri University Campus, P.O. BOX 14/6573, Hadath 02215, Lebanon; aelkak@ul.edu.lb \\ * Correspondence: jean-luc.boudenne@univ-amu.fr
}

check for updates

Citation: Azzi, M.; Ravier, S.; Elkak, A.; Coulomb, B.; Boudenne, J.-L. Fast UHPLC-MS/MS for the Simultaneous Determination of Azithromycin, Erythromycin, Fluoxetine and Sotalol in Surface Water Samples. Appl. Sci. 2021, 11, 8316. https://doi.org/10.3390/ app11188316

Academic Editor: Maris Klavins

Received: 29 July 2021

Accepted: 6 September 2021

Published: 8 September 2021

Publisher's Note: MDPI stays neutral with regard to jurisdictional claims in published maps and institutional affiliations.

Copyright: (c) 2021 by the authors. Licensee MDPI, Basel, Switzerland. This article is an open access article distributed under the terms and conditions of the Creative Commons Attribution (CC BY) license (https:/ / creativecommons.org/licenses/by/ $4.0 /)$.

\begin{abstract}
Chromatographic development for the determination of pharmaceuticals in environmental water samples is particularly challenging when the analytes have significantly different physicochemical properties (solubility, polarity, pKa) often requiring multiple chromatographic methods for each active component. This paper presents a method for the simultaneous determination of azithromycin, erythromycin (antibiotics), fluoxetine (anti-depressant) and sotalol (b-blocker) in surface waters by ultra-high-performance liquid chromatography coupled with ultra-high-resolution time-of-flight mass spectrometry. These pharmaceuticals-presenting a broad spectrum of polarity $\left(0.24 \leq \log \mathrm{K}_{\mathrm{ow}} \leq 4.05\right)$-were separated on a C-18 analytical column, after a simple filtration step for freshwater samples or after a liquid-liquid extraction with Methyl-tertio-butyl ether (MTBE) for seawater samples. The optimized separation method (in terms of nature of column and eluent, elution gradient, and of mass spectrometric parameters), enable one to reach limits of detection ranging between 2 and $7 \mathrm{ng} \mathrm{L}^{-1}$ and limits of quantification between 7 and $23 \mathrm{ng} \mathrm{L}^{-1}$ for the four targeted molecules, within a three minute run. This method was validated using samples collected from three different surface waters in Lebanon (freshwater and seawater) and analytical results were compared with those obtained in surface waters sampled in a French river, equivalent in terms of human activities. Using this method, we report the highest concentration of pharmaceuticals found in surface water (up to $377 \mathrm{ng} \mathrm{L}^{-1}$ and $268 \mathrm{ng} \mathrm{L}^{-1}$, respectively, for azithromycin and erythromycin, in the Litani river, Lebanon).
\end{abstract}

Keywords: emerging compounds; UHPLC-MS; pharmaceutically active compounds; occurrence; freshwater; seawater

\section{Introduction}

The water environment (freshwater, seawater, groundwater) is the ultimate repository from several classes or organic micro-pollutants emitted from different pollution sources $[1,2]$ from the direct discharge of untreated sewage or due to the limited efficiency of conventional wastewater treatment plants (WWTPs) [3-6]. Among these compounds, pharmaceuticals have become an issue of great concern for the scientific community politicians and the public $[7,8]$, as these compounds have been found to negatively affect freshwater fish and invertebrates as well as contribute to the development of antibiotic-resistant bacteria [9-13].

In the present paper, we chose to work on three classes of therapeutics, among the most sold and consumed in Lebanon and in France (therapeutics, anti-depressants and $\beta$-blockers), known for their eco-toxicities (based on their Predicted No-Effect Concentration (PNEC)), endocrine-disruption activities and their abilities to promote antimicrobial resistance [14-19]. To complete the selection of the molecules, and in line 
with the approach taken by several authors [20,21], we look at their incomplete metabolization (excretion factor), low removal in wastewater treatment plant and the frequency of their detection in aquatic environments [22-24]. This prioritization led us to select azythromycin and erithromycin (antibiotics), fluoxetine ([n-methyl-3-phenyl-3[4-(trifluoromethyl)phenoxy]propan-1-amine], also known by the trade names Prozac ${ }^{\circledR}$, Sarafem ${ }^{\circledR}$ or Fontex ${ }^{\circledR}$, anti-depressant) and sotalol ( $\beta$-blocker), also known by its trade names Betapace ${ }^{\circledR}$, Sorine ${ }^{\circledR}$ or Sotolyze ${ }^{\circledR}$, whose physical-chemical properties, ecotoxicities, excretions factors, and removal rates in wastewater plants are given Table 1.

As can be seen from the physical-chemical properties of these four molecules, their simultaneous determination may be challenging since these compounds present a wide range of properties such as polarity, solubility, acid dissociation constants, partition coefficients, and stabilities under acidic and basic conditions [25]. Even if ultra-high pressure liquid chromatography (UHPLC) and tandem mass spectroscopy $\left(\mathrm{MS}^{\mathrm{n}}\right)$ using updated source designs and acquisition methods is known to allow detection of pharmaceuticals at very low concentrations, especially by use of smaller particle size chromatographic columns (below $2.0 \mu \mathrm{m}$ ) [25-27], simultaneous determination of such compounds within the same chromatographic method has not been yet reported, even in papers dealing with multi-residue analysis of pharmaceuticals. Indeed, sotalol (hydrophilic and polar) is often better detected by use of an hydrophilic column [28], whereas fluoxetine and azithromycin (lipophilic and moderately polar) and erythromycin (lipophilic and non-polar) are separated by reversed-phase C18 $[26,27,29,30]$. In the present study, we developed a UHPLC-MS method using a novel column stationary phase capable of providing a selectivity within a wide elution window and increased retention for both polar and non-polar analytes.

Moreover, the analysis of the four targeted molecules has been conducted by direct injection without using sample preparation techniques such as Solid-Phase Extraction (SPE) to avoid matrix interferences that may affect electrospray ionization (signal suppression or enhancement), as already mentioned by several authors [17,31].

The need for an analysis that is cost-effective and easy to implement is important for laboratories conducting occurrence studies on pharmaceuticals in real waters. The UHPLCMS method allows for the first time the simultaneous determination of erythromycin, azithromycin, fluoxetine and sotalol in the same run and in a short, time-saving method.

The method was validated by measuring these compounds in real Lebanese and French freshwater and seawaters. 
Table 1. Physical-chemical properties, toxicities, excretion factors and wastewater removal rates of the four pharmaceuticals under study.

\begin{tabular}{|c|c|c|c|c|c|c|c|c|c|c|}
\hline $\begin{array}{c}\text { Pharmaceutical/CAS } \\
\text { Number }^{\mathrm{a}}\end{array}$ & $\begin{array}{l}\text { Chemical } \\
\text { Structure }\end{array}$ & $\begin{array}{l}\text { Molecular } \\
\text { Formula }\end{array}$ & $\begin{array}{c}\text { Molecular } \\
\text { Weight/Exact Mass } \\
\left(\mathrm{g} \mathrm{mol}^{-1}\right)\end{array}$ & $\begin{array}{c}\text { Solubility in } \\
\text { Water }^{b}\left(\mathrm{mg} \mathrm{L} \mathrm{L}^{-1}\right)\end{array}$ & $\log K_{\text {ow }}{ }^{c}$ & $\mathrm{pK}_{\mathrm{a}} \mathrm{d}^{\mathrm{a}}$ & $\log B C F^{e}$ & STP Removal ${ }^{\mathrm{f}}(\%)$ & $\begin{array}{l}\text { PNEC } \\
\left(\mu \mathrm{g} \mathrm{L}^{-1}\right)\end{array}$ & Excretion Factor ${ }^{h}(\%)$ \\
\hline Erythromycin/114-07-8 & & $\mathrm{C}_{37} \mathrm{H}_{67} \mathrm{NO}_{13}$ & $733.9 / 733.461241$ & 4.2 & 3.06 & $8.38 ; 12.44$ & 1.68 & 6.23 & 0.02 & 5 \\
\hline Azithromycin/83905-01-5 & & $\mathrm{C}_{38} \mathrm{H}_{72} \mathrm{~N}_{2} \mathrm{O}_{12}$ & $749 / 748.508526$ & 2.37 & 4.02 & $9.57 ; 12.43$ & 2.32 & 30.99 & 0.02 & 6 \\
\hline Fluoxetine/54910-89-3 & & $\mathrm{C}_{17} \mathrm{H}_{18} \mathrm{~F}_{3} \mathrm{NO}$ & $309.33 / 309.134049$ & 1.7 & 4.05 & 9.8 & 2.18 & 22.58 & 0.024 & 80 \\
\hline Sotalol/959-24-0 & & $\mathrm{C}_{12} \mathrm{H}_{20} \mathrm{~N}_{2} \mathrm{O}_{3} \mathrm{~S}$ & $272.37 / 272.119464$ & 780 & 0.24 & $9.43 ; 10.07$ & 0.5 & 1.85 & 13 & 75 \\
\hline
\end{tabular}

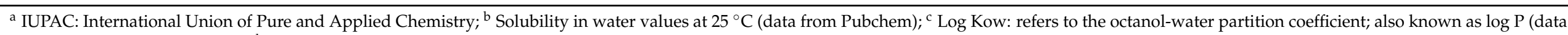

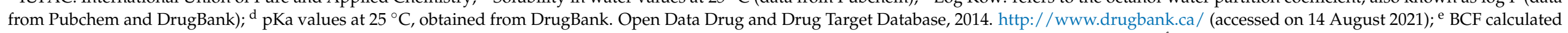

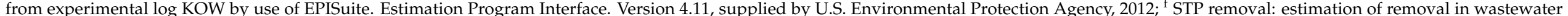

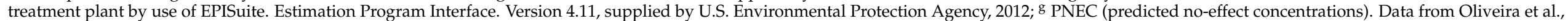
2015 [17]; ${ }^{h}$ excretion factor: correspond to the \% of unchanged molecule excreted by urine and feces. Data from Mansour et al., 2016. 


\section{Materials and Methods}

\subsection{Chemicals and Reagents}

Analytical standards of erythromycin, azithromycin dehydrate, fluoxetine hydrochloride and sotalol hydrochloride were purchased from Sigma-Aldrich (purity $>98 \%$ ) and were used as received. Their CAS numbers and their physical-chemical properties are detailed in Table 1. Acetonitrile Optima ${ }^{\circledR}$ LC/MS grade and formic acid Optima ${ }^{\circledR}$ LC/MS were purchased from Fisher Chemical. Triphenyl phosphate (TPP $\geq 99 \%$ ), obtained from Sigma-Aldrich, was used as internal standard.

Methyl tert-butyl ether (MTBE, Chromosolv, HPLC grade, Sigma-Aldrich, St. Louis, MI, USA) and sodium sulfate (Acros Organics) were readily used for liquid-liquid Extraction (LLE) of targeted analytes from seawater, as described in the experimental section.

\subsection{Preparation of Stock Solutions and Samples}

Glassware and sample bottles were scrupulously cleaned with hot water and detergent, thoroughly rinsed with tap and reagent water, and finally dried and heated in an oven at $400{ }^{\circ} \mathrm{C}$ for one hour. All glassware such cleaned was then sealed and stored, capped with aluminum foil, in a clean environment, before use. Volumetric ware was rinsed with acetone before storage and use.

All solutions were prepared in ultrapure water (MilliQ) generated from a Millipore water system (resistivity $>18 \mathrm{M} \Omega \mathrm{cm}$ ). Stock solutions of fluoxetine and sotalol were prepared weekly by dissolving in water, whereas erythromycin and azithromycin-slightly soluble in water (see Table 1) - were prepared by dissolving in a 50:50 (v:v) water-acetonitrile (ACN) mixture. These $1 \mathrm{mg} \mathrm{L}^{-1}$ stock solutions were then stored in amber glass at $4{ }^{\circ} \mathrm{C}$ until use, to prevent any form of degradation (e.g., photo- and/or hydrolysis). Working solutions were prepared with concentrations between 1-100 $\mathrm{g} \mathrm{L} \mathrm{L}^{-1}$ for the four compounds, and were used for subsequent dilution into acidified media ( $0.1 \%$ formic acid) for calibration. Standard mixes were made daily, stored at $4{ }^{\circ} \mathrm{C}$, and monitored for changes in sensitivity.

Freshwater samples were merely filtrated using a syringe filter of $4 \mathrm{~mm}$ diameter (porosity $0.2 \mu \mathrm{m}$, PTFE $100 \mathrm{PK}$ ) purchased from RESTEK before analysis.

Seawater samples were filtrated in the same way. Molecules of interest were then extracted from the saline matrix by liquid-liquid extraction (LLE) with MTBE. Briefly, $4 \mathrm{~mL}$ MTBE is added to a $40 \mathrm{~mL}$ sample. Sodium sulfate $(8 \mathrm{~g})$ was then added to enhance the separation of the two liquid phases. Glass cylinders were vigorously and consistently shaken manually for $4 \mathrm{~min}$ until reagents were totally dissolved. Water and MTBE phases are finally allowed to separate for $3 \mathrm{~min}$. Organic extracts were then analyzed by highperformance liquid chromatography coupled with ultra-high-resolution time-of-flight mass spectrometry (UHPLC-q-ToF-MS).

\subsection{Instrumental Analysis}

UHPLC-q-ToF-MS analysis was performed using an UPLC system (Acquity, Waters, MA, USA) interfaced with a quadrupole/time-of-flight mass spectrometer (Q/ToF-MS) equipped with an electrospray ion (ESI) source (Synapt G2 HDM, Waters, MA, USA). The autosampler (Sample Manager, Acquity, Waters, MA, USA) temperature was set at $5{ }^{\circ} \mathrm{C}$. Data acquisition and mass spectra treatments were provided by the MassLyn $x^{\mathrm{TM}}$ software (v.4.1, Waters, MA, USA).

The chromatographic separations were tested with 4 different columns: Acquity UPLC HSS PFP (PentaFluoroPhenyl), $100 \AA, 1.8 \mu \mathrm{m}, 2.1 \mathrm{~mm} \times 100 \mathrm{~mm}$; Cortecs UPLC C18 $90 \AA$, $1.6 \mu \mathrm{m}, 2.1 \mathrm{~mm} \times 100 \mathrm{~mm}$; Acquity UPLC BEH C18 Column, $130 \AA ̊ 丿, 1.7 \mu \mathrm{m}, 2.1 \mathrm{~mm} \times 50 \mathrm{~mm}$; Phenomenex Luna Omega, $100 \AA$, $1.6 \mu \mathrm{m}$, Polar C18 $50 \mathrm{~mm} \times 2.1 \mathrm{~mm}$.

Optimal separation was achieved on a Phenomenex Luna Omega column, by using gradient elution with $0.1 \%$ formic acid in water $(v / v$, eluent $\mathrm{A}$ ) and $0.1 \%$ in acetonitrile (eluent $\mathrm{B}$ ) at a flow rate of $0.4 \mathrm{~mL} / \mathrm{min}$. The gradient was as follows: $0-3 \mathrm{~min}$ from $2 \%$ to $70 \% \mathrm{~B} ; 3-3.5 \mathrm{~min}$ from $70 \%$ to $95 \% \mathrm{~B} ; 3.5-4 \mathrm{~min}$ from $95 \%$ to $2 \% \mathrm{~B}$ (initial conditions); 4-7 min (reconditioning). The injection volume was $10 \mu \mathrm{L}$. 


\subsection{Sampling Sites and Sample Collection}

To determine the occurrence of the selected pharmaceuticals in surface waters in Lebanon, the developed method was applied on water samples taken from 3 sites in Lebanon and 3 sites in France (Figure 1). The first sampling site (A) was located in the Litani river, the largest river in Lebanon with $170 \mathrm{~km}$ in length and with an average annual flow of 920 million cubic meters. This river rises in the Beqaa Valley (west of Baalbek) and empties in the Mediterranean Sea (north of Tyre). The second sampling point was in the Damour river (B). This $37.5 \mathrm{~km}$ coastal river with an average annual flow of 307,000 cubic meters, located in the Mount Lebanon Governorate, originates from Barouk mountain, and flows west through the Jisr Al-Kadi valley, where it receives water from the creeks of the Chouf mountains, and empties into the Mediterranean Sea, south of Damour. The third sampling point (C) was located at $5 \mathrm{~km}$ to the south of the capital of Beirut directly at the discharging site of Al-Ghadir wastewater treatment plant. This plant is theoretically designed for 400,000 citizens of the southern suburbs of Greater Beirut but receives wastewaters from more than one million inhabitants. Three other samplings were carried out in Southern France along the Arc River, an $83 \mathrm{~km}$ river rising in Pourcieux and flowing in Berre Lagoon, directly connected to the Mediterranean Sea. This river notably flows through the city of Aix-en-Provence, and receives the discharges of several wastewater treatment plants, among them two located in southwestern Aix-en-Provence (150,000 pe) and western Aixen-Provence (30,000 pe). Samples D, E, and F were, respectively, taken at the outlet of the first wastewater treatment plant (La Pioline, Aix-en-Provence, France), at the outlet of the second wastewater treatment plant (Aix-Ouest), and F (Roquefavour), $10 \mathrm{~km}$ downstream of the sampling point $\mathrm{E}$.

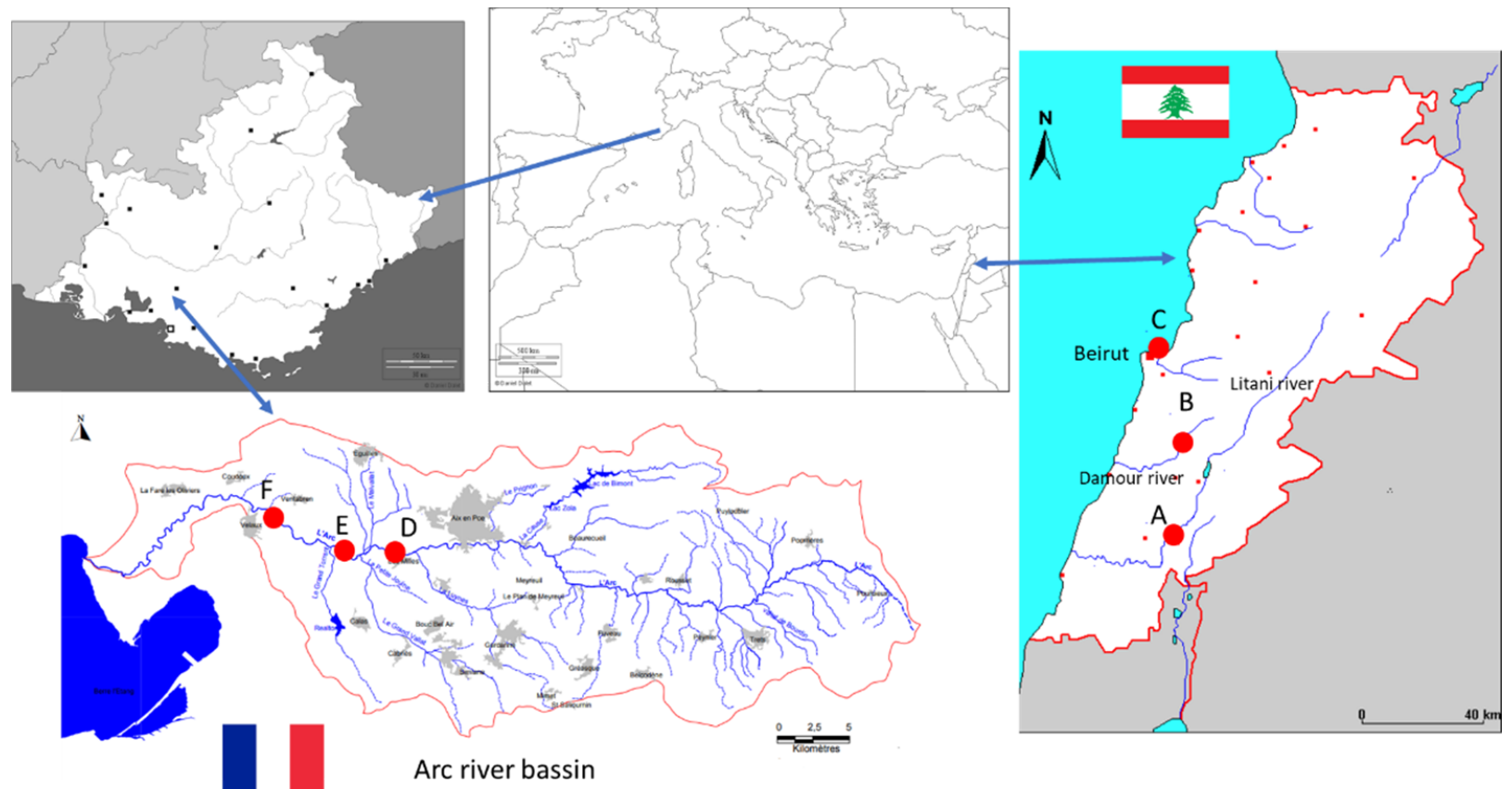

Figure 1. Sampling sites in Lebanon and in France. A, B, C red circles on the right represent the samples sites located in Lebanon: (A) Litani river; (B) Damour river; (C) Al Ghadir. D, E and red circles on the left represent the samples sites located in France: (D) downstream of WWTP1; (E) downstream of WWTP2; (F) Roquefavour.

Samples were collected in duplicates from the mentioned locations in amber glass bottles and stored in a cooler with ice until transportation to the laboratory for analysis. Moreover, samples were taken in a period between July 2019 and August 2019 (in Lebanon) and in September 2019 in France. 


\section{Results and Discussions}

\subsection{Method Development}

As previously mentioned, azithromycin, erythromycin, fluoxetine and sotalol possess dissimilar physical-chemical properties (solubility, polarity, partition coefficient), and the necessity of their separation, identification and quantification in the same and timeeffective analytical run and under the same experimental conditions, choice of the column and nature of the eluent are determining factors. During the method development, four HPLC columns were tested for the separation of target pharmaceuticals. In the preliminary phase, a mobile phase made of $10 \%$ water and $90 \%$ ACN in $\mathrm{MeOH}$ was tested as eluent.

The first column was a pentafluorophenyl (PFP) column from waters. Columns made of PFP as stationary phase are originally designed for separation of cyclic compounds [32] and have already been used successfully for the separation of macrolides (among them, azithromycin, and erythromycin) [33]. The elution peaks of the four compounds were differentiated with a moderate resolution, but sotalol could only be detected using ESI in negative mode.

We then tested two other columns from waters: Cortecs UPLC ${ }^{\mathrm{TM}}$ C18 and UPLC ${ }^{\mathrm{TM}}$ BEH $\mathrm{C} 18$. The first one is made of $1.6 \mu \mathrm{m}$ solid-core particles, while the second one is made of $1.7 \mu \mathrm{m}$ porous particles having a bridged ethyl-siloxane silica hybrid (BEH) structure. Both are expected to improve resolution and efficiency of separation and have been successfully used for determination of pharmaceuticals (except sotalol) in water matrices [17,27,34,35]. These columns were assessed with a gradient elution $0.1 \%$ ammonium formate (AF) used as aqueous eluent, while $0.1 \%$ to $0.3 \% \mathrm{AF}$ in $\mathrm{ACN}$ were tested as organic eluents, based on the assumption that shifting $\mathrm{pH}$ to acid will serve a better separation of targeted molecules. The $0.3 \%$ AF was quickly abandoned because this amount rusted the capillary used for electro-spraying. Moreover, these two columns were found to be unsuitable, due to the pronounced peak broadening of azithromycin and erythromycin.

Finally, the highest resolution combined to the lowest retention times for analyte separations (see Appendix A) were achieved using a PHENOMENEX Luna Omega $1.6 \mu \mathrm{m}$ Polar C18 $50 \times 2.1 \mathrm{~mm}$ at $40^{\circ} \mathrm{C}$, thus selected for the further method development. This stationary phase column is able to provide a selectivity within a wide elution window and increased retention for both polar and non-polar analytes. The C18 ligand provides hydrophobic interactions while a polar modified particle surface provides enhanced polar retention and aqueous stability.

Using a mobile phase consisting of A: $0.1 \%$ FA in ultra-pure water and B: $0.1 \% \mathrm{FA}$ in UHPLC/MS grade allowed us to avoid tailing and fronting of chromatographic peaks. Elution mode was performed as non-isocratic gradient for standard separation and quantification of analytes at a flow rate of $0.4 \mathrm{~mL} \mathrm{~min}^{-1}$. A multi-step gradient was thus used as follows, initial conditions: 2\% B; 0.0-3.0 min, 70\% B; 3.0-3.5 min, 95\% B; 3.5-4.0 min, return to initial conditions; $2 \% \mathrm{~B} ; 4.0-7.0 \mathrm{~min}$, re-equilibration of the column. Before injection, samples in vials were acidified with $0.1 \%$ FA. The sample injection volume was $10 \mu \mathrm{L}$. The ESI source contained two individual orthogonal sprays. One spray was for the column eluent while the other was for the internal standard (lock mass). During each chromatographic run, leucine enkephalin ( $2 \mathrm{mg} \mathrm{L}^{-1}, \mathrm{C}_{28} \mathrm{H}_{37} \mathrm{~N}_{5} \mathrm{O}_{7}, \mathrm{MW} 555.27$, waters Q-ToF product) was used for lock-mass correction to obtain accurate masses for each organic component eluting from the column. A solution of sodium formate (HCOONa, waters Q-ToF product) was infused daily in the ESI source to calibrate the instrument.

The optimum mass spectrometric parameters were found using a $2 \mathrm{kV}$ capillary voltage, $500{ }^{\circ} \mathrm{C}$ desolvation temperature, $150{ }^{\circ} \mathrm{C}$ source temperature, $10 \mathrm{~L} \mathrm{~h}^{-1}$ cone gas flow rate and $1000 \mathrm{~L} \mathrm{~h}^{-1}$ desolvation gas flow rate. The ESI source has been optimized directly with the samples and was operated in a positive mode. These parameters allowed the increase of the signal to noise ratio, maintaining a soft ionization technique to obtain the optimum fragmentation. Data were collected from 50 to $1200 \mathrm{Da}$ in the PI. The mass spectrometer was used in its resolution mode. Compounds were detected as their protonated molecules $\left([\mathrm{M}+\mathrm{H}]^{+}\right)$since all of them responded in the positive ionization 
acquisition mode. Significantly, experiments were repeated at least four times so that one may be sure of the accuracy, sensitivity, and selectivity of the analysis in the developed operation conditions.

MS/MS transitions and operating conditions ( $\mathrm{m} / \mathrm{z}$, cone voltage, collision energy) used for quantification for each pharmaceutical are described in Table 2.

Table 2. Pharmaceuticals retention time and MS/MS operating conditions.

\begin{tabular}{cccccc}
\hline Analyte & RT (min) & Parent Ion $[\mathbf{M}+\mathbf{H}]^{+}$ & Cone Voltage (V) & Fixed CE Value (V) & Fragments \\
\hline Azithromycin & 1.71 & 749.5164 & 45 & 25 & 591.422 \\
Erythromycin & 2.19 & 734.4691 & 20 & 14 & 576.374 \\
Fluoxetine & 2.47 & 310.1419 & 20 & 4 & 148.113 \\
Sotalol & 1.02 & 273.1273 & 20 & 4 & 255.117 \\
& & & & 213.07 \\
\hline
\end{tabular}

Representative chromatograms of the selected pharmaceuticals, along with their mass spectrum, is presented in Appendix B.

\subsection{Analytical Features}

Working solutions, prepared as previously mentioned in Section 2.2, were used to spike either pure water or synthetic seawater to create the calibration standards used to generate calibration curves for each compound of interest. Synthetic seawater was prepared according to the ASTM international standard practice for the preparation of substitute ocean water (method D1141-98, 2013). At least five calibration standards were used to prepare the calibration curves, either directly or after extraction with MTBE for seawater solutions. The calibration curves were drawn up by the relative responses obtained when analyzing the standards in relation to the internal standard (triphenyl phosphate) as a function of the standard concentration. Quantitation of pharmaceuticals was performed by following the same procedure used to establish the calibration curves. MS/MS transitions used for quantitation of the pharmaceuticals are described in Table 2.

Pharmaceuticals thus detected were identified based on matching the retention times and the relative intensity ratio of transition ions with those of the standards. Quantitation was performed using the ion transition representing the highest abundance. The performance parameters of the analytical method are presented in Table 3.

Table 3. LC-MS/MS method performance characteristics for the analysis of pharmaceuticals.

\begin{tabular}{|c|c|c|c|c|c|c|}
\hline Compound & Precision (\%) & Linearity $\left(r^{2}\right)$ & Range (ng $L^{-1}$ ) & LOD (ng L $\left.{ }^{-1}\right)$ & LOQ (ng $\left.L^{-1}\right)$ & Recovery (\%) \\
\hline Fluoxetine & 16 & 0.994 & $1-1000$ & 2 & 7 & 87 \\
\hline Sotalol & 13 & 0.993 & $2-1000$ & 2 & 6.8 & 105 \\
\hline Azithromycin & 14 & 0.993 & $2-1000$ & 2 & 8 & 92 \\
\hline Erythromycin & 8 & 0.990 & 5-1000 & 7 & 23 & 98 \\
\hline
\end{tabular}

Method accuracy was validated by calculating the percent recovery using nine determinations over three concentration levels (at the LOQ, and at middle and high concentration points of the calibration curve) in seawater and in freshwater matrices representative of the planned sampling campaign. As shown in Table 3, repeatability relative standard deviation (RSD) ranged between $8 \%$ and $16 \%$, and mean recovery covered $87 \%$ to $105 \%$ of the test concentrations. Within the studied concentration range, the calibration curves were linear $\left(\mathrm{r}^{2} \geq 0.99\right)$. The limits of detection (LOD) were determined as a signal-to-noise ratio 3:1 and ranged between 2 and $7 \mathrm{ng} \mathrm{L}^{-1}$. Limits of quantitation (LOQ) were determined based on a signal-to-noise ratio 10:1 and ranged from $7 \mathrm{ng} \mathrm{L}^{-1}$ to $23 \mathrm{ng} \mathrm{L}{ }^{-1}$. These limits are in line with levels obtained in previous studies using direct injection coupled to UHPLC-MS/MS $[17,36]$. 


\subsection{Application to Real Field Samples}

Samples collected in France and in Lebanon between July and September 2019 were analyzed according to the method developed. Samples were analyzed in triplicate and results with standard deviation are reported Table 4.

Table 4. Levels of pharmaceuticals found in France and in Lebanon $\left(\mathrm{ng} \mathrm{L}^{-1}\right)$.

\begin{tabular}{|c|c|c|c|c|}
\hline & Azithromycin & Erythromycin & Fluoxetine & Sotalol \\
\hline \multicolumn{5}{|l|}{ Lebanon } \\
\hline Station A & $377.7 \pm 22.2$ & $268.3 \pm 32$ & $28.4 \pm 4.2$ & $44.8 \pm 4.3$ \\
\hline Station B & $161.6 \pm 21.7$ & $121 \pm 12.3$ & $12.6 \pm 2.4$ & \\
\hline $\begin{array}{l}\text { Station C } \\
\text { France }\end{array}$ & $10.8 \pm 6.4$ & & & \\
\hline Station D & $3.75 \pm 0.20$ & & & $2.35 \pm 0.27\left(^{*}\right)$ \\
\hline Station E & $4.99 \pm 0.83$ & & & $2.15 \pm 0.86\left(^{*}\right)$ \\
\hline Station F & $17 \pm 2.3$ & & & $5.07 \pm 1.01\left(^{*}\right)$ \\
\hline
\end{tabular}

Azithromycin was found in the whole samples with levels varying between 10.8 and $377.7 \mathrm{ng} \mathrm{L}^{-1}$ in Lebanon, and between 3.75 and $17 \mathrm{ng} \mathrm{L}^{-1}$ in France. Erythromycin and fluoxetine were only quantified in Lebanese freshwaters at levels between 121 and $268 \mathrm{ng} \mathrm{L}^{-1}$, and 12.6 and $28.4 \mathrm{ng} \mathrm{L}^{-1}$, respectively. Sotalol was found in the whole samples in France, with a concentration gradient; levels increased from upstream to downstream of the Arc river, from 2.1 to $5.0 \mathrm{ng} \mathrm{L}^{-1}$. In Lebanon, this compound was only detected in the Litani river $\left(44 \mathrm{ng} \mathrm{L}^{-1}\right)$.

Highest levels of targeted molecules in Lebanese freshwater may be explained by the low volumes of wastewater that are treated before discharge in the environment (below $10 \%)[19,37]$, or simply lack of wastewater infrastructure with used waters only relying on open sewers, septic tanks, or simply discharge wastewater directly into the environment, as evidenced by very high counts of fecal and total coliforms, inorganic and organic pollutants recorded in rivers, watersheds and groundwater [19]. However, it should also be noticed that these molecules are known to be poorly eliminated in wastewater treatment plants, with removal rates between 1.9\% (sotalol) and 31\% (azithromycin) (Table 1). This explains that azithromycin and sotalol are detectable in freshwaters in France, especially at the outlets of wastewater treatment plants. Moreover, consumption of pharmaceuticals is particularly high in France with a per capita consumption of pharmaceuticals of $150 \mathrm{~g}$ vs. $49 \mathrm{~g}$ per capita in Lebanon [19]. This study is the first one to reveal the presence of sotalol, fluoxetine and erythromycin in Lebanese freshwaters. Overall, data on the occurrence of pharmaceuticals in Lebanese water are scarce. Only one paper reported, until now, the occurrence of pharmaceuticals in Lebanon [38] and has shown the presence of erythromycin at levels up to $98 \mathrm{ng} \mathrm{L}^{-1}$ in the Ibrahim river.

These new data emphasize the needs to implement a large survey of pharmaceuticals at the country level in Lebanon.

\section{Conclusions}

In this study, a method for the simultaneous analysis of pharmaceuticals-belonging to three different therapeutic classes-using UHPLC-MS/MS was developed and optimized. The proposed method has been applied to four molecules, prioritized according to their consumption in Lebanon and in France, excretion factor, wastewater removal rates and environmental risks. It is supposed that this simple, fast and easy to perform method may be applied to other pharmaceuticals presenting dissimilar physical properties.

Its application in Lebanese and French surface waters underlines the needs to continue with studies to map the "pharmaceutical impregnation" of surface waters in Lebanon to prioritize implementation of wastewater infrastructures and use of advanced oxidation processes to remove these compounds. 
Author Contributions: Conceptualization, J.-L.B.; methodology, M.A.; software, S.R.; validation, B.C.; formal analysis, M.A.; investigation, M.A.; writing-original draft preparation, J.-L.B.; supervision, A.E. and J.-L.B. All authors have read and agreed to the published version of the manuscript.

Funding: This research received no external funding.

Institutional Review Board Statement: Not applicable.

Informed Consent Statement: Not applicable.

Acknowledgments: Mira Azzi acknowledges the doctoral school of Environmental Sciences (ED251) and the faculty of pharmacy in the Lebanese University for the doctoral scholarship.

Conflicts of Interest: The authors declare no conflict of interest.

\section{Appendix A}

Table A1. Comparison of individual column tested.

\begin{tabular}{cccccccccc}
\hline Column & \multicolumn{3}{c}{ CORTECS C-18 } & \multicolumn{2}{c}{ BEH C-18 } & \multicolumn{2}{c}{ Luna Omega C-18 } \\
\hline Compound & $\mathbf{R}_{\mathbf{S}}$ & $\mathbf{R T}$ (min) & Width (min) & $\mathbf{R}_{\mathbf{S}}$ & RT (min) & Width (min) & R $_{\mathbf{S}}$ & RT (min) & Width (min) \\
Sotalol & & 5.2 & 0.02 & & 6.8 & 0.03 & 0.01 & 1.02 \\
Azithromycin & 6.9 & 6.3 & 0.30 & 4.6 & 7.9 & 0.45 & 8.6 & 1.71 \\
Erythromycin & 2.6 & 7.2 & 0.40 & 0.8 & 8.3 & 0.57 & 5.0 & 2.19 \\
Fluoxetine & 3.5 & 8 & 0.05 & 9.6 & 12 & 0.2 & 11.2 & 2.47 \\
\hline
\end{tabular}

$\mathrm{RT}$ = retention time; $\mathrm{R}_{\mathrm{S}}=$ resolution; Width: peak width of considered peak at baseline.

\section{Appendix B}
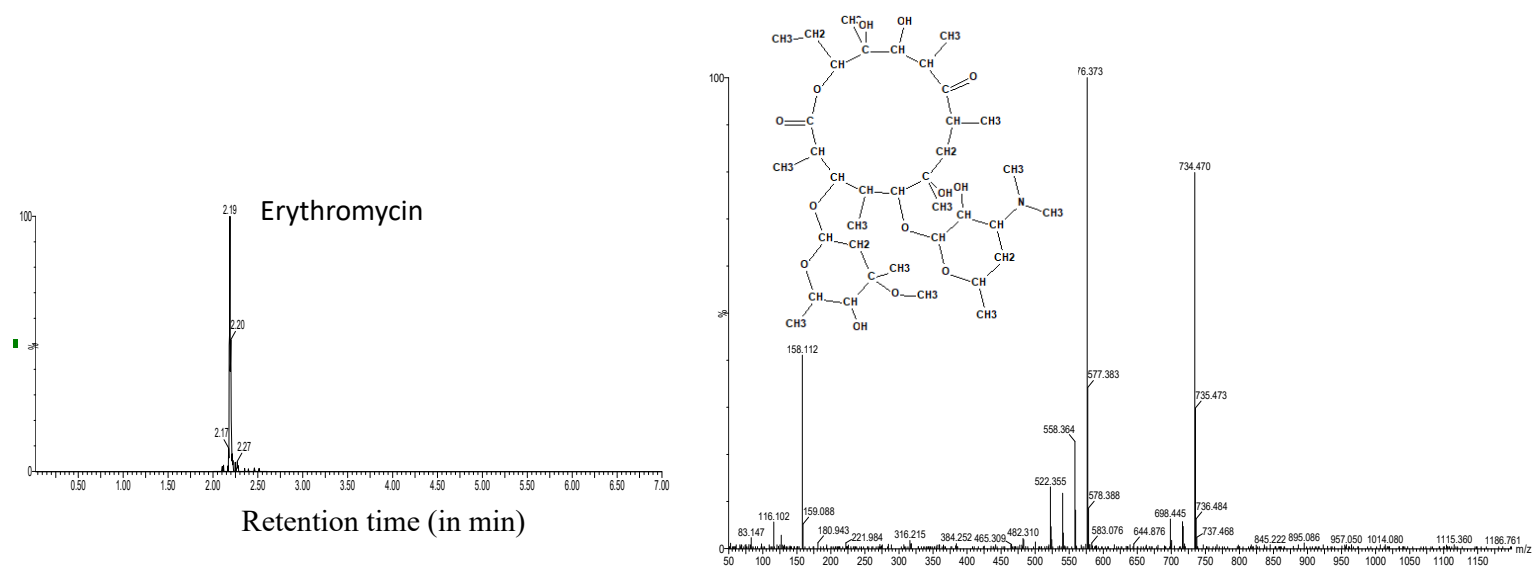

$\mathrm{m} / \mathrm{Z}$ (Relative abundance vs. mass-to-charge)
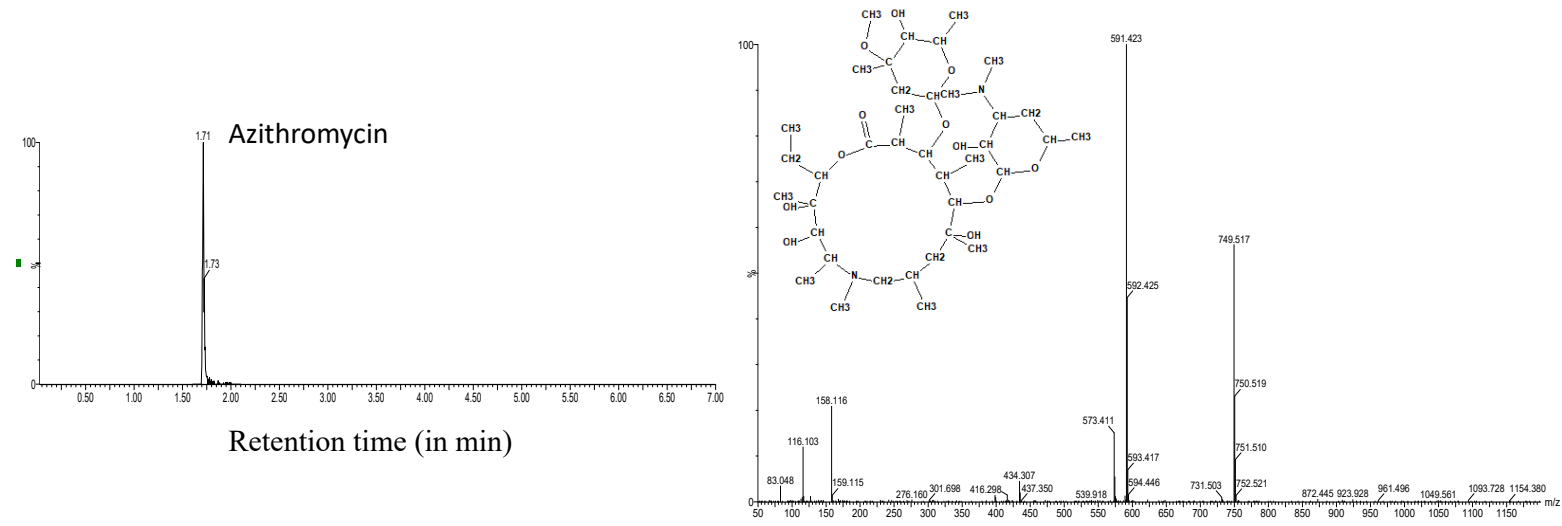

$\mathrm{m} / \mathrm{Z}$ (Relative abundance vs. mass-to-charge)

Figure A1. Cont. 

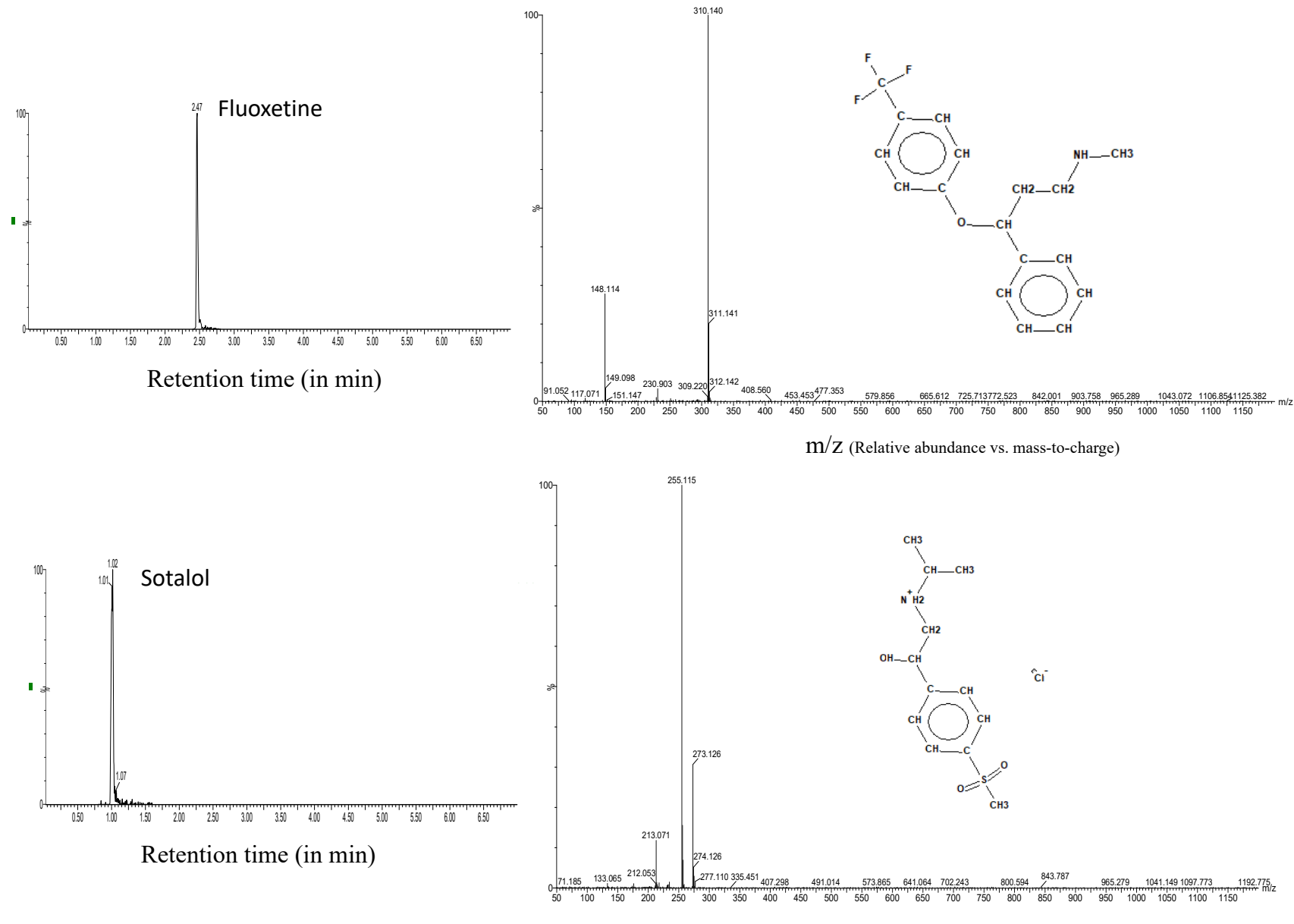

$\mathrm{m} / \mathrm{Z}$ (Relative abundance vs. mass-to-charge)

Figure A1. Chromatograms and mass spectra of the four molecules under study.

\section{References}

1. Richardson, S.D.; Kimura, S.Y. Emerging environmental contaminants: Challenges facing our next generation and potential engineering solutions. Environ. Technol. Innov. 2017, 8, 40-56. [CrossRef]

2. Beckers, L.M.; Brack, W.; Dann, J.P.; Krauss, M.; Müller, E.; Schulze, T. Unraveling longitudinal pollution patterns of organic micropollutants in a river by non-target screening and cluster analysis. Sci. Total Environ. 2020, 727, 138388. [CrossRef]

3. Müller, M.E.; Werneburg, M.; Glaser, C.; Schwientek, M.; Zarfl, C.; Escher, B.I.; Zwiener, C. Influence of Emission Sources and Tributaries on the Spatial and Temporal Patterns of Micropollutant Mixtures and Associated Effects in a Small River. Environ. Toxicol. Chem. 2020, 39, 1382-1391. [CrossRef]

4. Tosun, J.; Schaub, S.; Fleig, A. What determines regulatory preferences? Insights from micropollutants in surface waters. Environ. Sci. Policy 2020, 106, 136-144. [CrossRef]

5. Zahn, D.; Neuwald, I.J.; Knepper, T.P. Analysis of mobile chemicals in the aquatic environment-current capabilities, limitations and future perspectives. Anal. Bioanal. Chem. 2020, 412, 4763-4784. [CrossRef]

6. Arlos, M.J.; Schürz, F.; Fu, Q.; Lauper, B.B.; Stamm, C.; Hollender, J. Coupling river concentration simulations with a toxicokinetic model effectively predicts the internal concentrations of wastewater-derived micropollutants in field gammarids. Environ. Sci. Technol. 2020, 54, 1710-1719. [CrossRef]

7. Gros, M.; Petrović, M.; Barceló, D. Development of a multi-residue analytical methodology based on liquid chromatographytandem mass spectrometry (LC-MS/MS) for screening and trace level determination of pharmaceuticals in surface and wastewaters. Talanta 2006, 70, 678-690. [CrossRef]

8. Roig, B.; Greenwood, R.; Barcelò, D. An international conference on pharmaceuticals in the environment in a frame of EU Knappe project. Environ. Int. 2009, 35, 763-765. [CrossRef] [PubMed]

9. Pal, A.; Gin, K.Y.H.; Lin, A.Y.C.; Reinhard, M. Impacts of emerging organic contaminants on freshwater resources: Review of recent occurrences, sources, fate and effects. Sci. Total Environ. 2010, 408, 6062-6069. [CrossRef] [PubMed]

10. Guardabassi, L.; Petersen, A.; Olsen, J.E.; Dalsgaard, A. Antibiotic resistance in Acinetobacter spp. isolated from sewers receiving waste effluent from a hospital and a pharmaceutical plant. Appl. Environ. Microbiol. 1998, 64, 3499-3502. [CrossRef] [PubMed] 
11. Michael, I.; Rizzo, L.; McArdell, C.S.; Manaia, C.M.; Merlin, C.; Schwartz, T.; Dagot, C.; Fatta-Kassinos, D. Urban wastewater treatment plants as hotspots for the release of antibiotics in the environment: A review. Water Res. 2013, 47, 957-995. [CrossRef]

12. Fent, K.; Weston, A.A.; Caminada, D. Ecotoxicology of human pharmaceuticals. Aquat. Toxicol. 2006, 76, 122-159. [CrossRef] [PubMed]

13. Huerta-Fontela, M.; Galceran, M.T.; Ventura, F. Illicit drugs in the urban water cycle. In Xenobiotics in the Urban Water Cycle; Fatta-Kassinos, D., Bester, K., Kümmerer, K., Eds.; Springer: Berlin/Heidelberg, Germany, 2010; pp. 51-71.

14. Cao, J.; Fu, B.; Zhang, T.; Wu, Y.; Zhou, Z.; Zhao, J.; Yang, E.; Qian, T.; Luo, J. Fate of typical endocrine active compounds in full-scale wastewater treatment plants: Distribution, removal efficiency and potential risks. Bioresour. Technol. 2020, 310, 123436. [CrossRef]

15. Monson, C.; Young, G.; Schultz, I. In vitro exposure of vitellogenic rainbow trout ovarian follicles to endocrine disrupting chemicals can alter basal estradiol-17 $\beta$ production and responsiveness to a gonadotropin challenge. Aquat. Toxicol. 2019, 217, 105346. [CrossRef]

16. Godoy, A.A.; de Oliveira, A.C.; Silva, J.G.M.; Azevedo, C.C.d.J.; Domingues, I.; Nogueira, A.J.A.; Kummrow, F. Single and mixture toxicity of four pharmaceuticals of environmental concern to aquatic organisms, including a behavioral assessment. Chemosphere 2019, 235, 373-382. [CrossRef]

17. Oliveira, T.S.; Murphy, M.; Mendola, N.; Wong, V.; Carlson, D.; Waring, L. Characterization of pharmaceuticals and personal care products in hospital effluent and wastewater influent/effluent by direct-injection LC-MS-MS. Sci. Total Environ. 2015, 518-519, 459-478. [CrossRef] [PubMed]

18. Neto, J.B.A.; Josino, M.A.A.; da Silva, C.R.; Campos, R.S.; do Nascimento, F.B.S.A.; Sampaio, L.S.; Valente Sá, L.G.d.A.; Carneiro, I.S.; Barroso, F.D.D.; da Silva, L.J.; et al. A mechanistic approach to the in-vitro resistance modulating effects of fluoxetine against meticillin resistant Staphylococcus aureus strains. Microb. Pathog. 2019, 127, 335-340. [CrossRef] [PubMed]

19. Mansour, F.; Al-Hindi, M.; Saada, W.; Salamb, D. Environmental risk analysis and prioritization of pharmaceuticals in a developing world context. Sci. Total Environ. 2016, 557-558, 31-43. [CrossRef] [PubMed]

20. Al Aukidy, M.; Verlicchi, P.; Voulvoulis, N. A framework for the assessment of the environmental risk posed by pharmaceuticals originating from hospital effluents. Sci. Total Environ. 2015, 493, 54-64. [CrossRef] [PubMed]

21. Li, Y.; Zhang, L.; Ding, J.; Liu, X. Prioritization of pharmaceuticals in water environment in China based on environmental criteria and risk analysis of top-priority pharmaceuticals. J. Environ. Manag. 2020, 253, 109732. [CrossRef] [PubMed]

22. Kümmerer, K. Antibiotics in the aquatic environment-A review-Part II. Chemosphere 2009, 75, 435-441. [CrossRef]

23. Sangion, A.; Gramatica, P. PBT assessment and prioritization of contaminants of emerging concern: Pharmaceuticals. Environ. Res. 2016, 147, 297-306. [CrossRef]

24. Paíga, P.; Santos, L.H.M.L.M.; Delerue-Matos, C. Development of a multi-residue method for the determination of human and veterinary pharmaceuticals and some of their metabolites in aqueous environmental matrices by SPE-UHPLC-MS/MS. J. Pharm. Biomed. Anal. 2017, 135, 75-86. [CrossRef]

25. Primel, E.G.; Caldas, S.S.; Escarrone, A.L.V. Multi-residue analytical methods for the determination of pesticides and PPCPs in water by LC-MS/MS: A review. Cent. Eur. J. Chem. 2012, 10, 876-899. [CrossRef]

26. Gurke, R.; Rossmann, J.; Schubert, S.; Sandmann, T.; Rößler, M.; Oertel, R.; Fauler, J. Development of a SPE-HPLC-MS/MS method for the determination of most prescribed pharmaceuticals and related metabolites in urban sewage samples. J. Chromatogr. B Anal. Technol. Biomed. Life Sci. 2015, 990, 23-30. [CrossRef] [PubMed]

27. Orfanidis, A.; Gika, H.; Theodoridis, G.; Mastrogianni, O.; Raikos, N. Development of a UHPLC-MS/MS method for the determination of 84 pharmaceuticals and drugs of abuse in human liver. J. Chromatogr. B Anal. Technol. Biomed. Life Sci. 2020, 1151, 122192. [CrossRef] [PubMed]

28. Feng, Z.; Yu, S.; Liu, W.; Yang, L.; Liu, Y.; Zhai, S.; Wang, F.; Zhang, X. A simple and sensitive LC-MS/MS method for the determination of sotalol in rat plasma. Biomed. Chromatogr. 2015, 29, 1167-1172. [CrossRef] [PubMed]

29. Alves, V.; Gonçalves, J.; Conceição, C.; Teixeira, H.M.; Câmara, J.S. An improved analytical strategy combining microextraction by packed sorbent combined with ultra-high pressure liquid chromatography for the determination of fluoxetine, clomipramine and their active metabolites in human urine. J. Chromatogr. A 2015, 1408, 30-40. [CrossRef] [PubMed]

30. Jank, L.; Martins, M.T.; Arsand, J.B.; Motta, T.M.C.; Hoff, R.B.; Barreto, F.; Pizzolato, T.M. High-throughput method for macrolides and lincosamides antibiotics residues analysis in milk and muscle using a simple liquid-liquid extraction technique and liquid chromatography-electrospray-tandem mass spectrometry analysis (LC-MS/MS). Talanta 2015, 144, 686-695. [CrossRef] [PubMed]

31. Yu, K.; Li, B.; Zhang, T. Direct rapid analysis of multiple PPCPs in municipal wastewater using ultrahigh performance liquid chromatography-tandem mass spectrometry without SPE pre-concentration. Anal. Chim. Acta 2012, 738, 59-68. [CrossRef] [PubMed]

32. Borova, V.L.; Gago-Ferrero, P.; Pistos, C.; Thomaidis, N.S. Multi-residue determination of 10 selected new psychoactive substances in wastewater samples by liquid chromatography-tandem mass spectrometry. Talanta 2015, 144, 592-603. [CrossRef]

33. Senta, I.; Krizman-Matasic, I.; Terzic, S.; Ahel, M. Comprehensive determination of macrolide antibiotics, their synthesis intermediates and transformation products in wastewater effluents and ambient waters by liquid chromatography-tandem mass spectrometry. J. Chromatogr. A 2017, 1509, 60-68. [CrossRef] 
34. Guichard, N.; Fekete, S.; Guillarme, D.; Bonnabry, P.; Fleury-Souverain, S. Computer-assisted UHPLC-MS method development and optimization for the determination of 24 antineoplastic drugs used in hospital pharmacy. J. Pharm. Biomed. Anal. 2019, 164, 395-401. [CrossRef] [PubMed]

35. Poirier-Larabie, S.; Houde, M.; Gagnon, C. Determination of the bioavailability of selected pharmaceutical residues in fish plasma using liquid chromatography coupled to tandem mass spectrometry. J. Chromatogr. A 2017, 1522, 48-55. [CrossRef] [PubMed]

36. Campos-Manas, M.C.; Plaza-Bolanos, P.; Sánchez-Pérez, J.A.; Malato, S.; Agüera, A. Fast determination of pesticides and other contaminants of emerging concern in treated wastewater using direct injection coupled to highly sensitive ultra-high performance liquid chromatography-tandem mass spectrometry. J. Chromatogr. A 2017, 1507, 84-94. [CrossRef]

37. Desbiolles, F.; Malleret, L.; Tiliacos, C.; Wong-Wah-Chung, P.; Laffont-Schwob, I. Occurrence and ecotoxicological assessment of pharmaceuticals: Is there a risk for the Mediterranean aquatic environment? Sci. Total Environ. 2018, 639, 1334-1348. [CrossRef]

38. Mokh, S.; El Khatib, M.; Koubar, M.; Daher, Z.; Al Iskandarani, M. Innovative SPE-LC-MS/MS technique for the assessment of 63 pharmaceuticals and the detection of antibiotic-resistant-bacteria: A case study natural water sources in Lebanon. Sci. Total Environ. 2017, 609, 830-841. [CrossRef] [PubMed] 